Available online on 15.05.2020 at http://ujpr.org
Universal Journal of Pharmaceutical Research
An International Peer Reviewed Journal
Open access to Pharmaceutical research

\title{
LEVEL OF LEAD IN THE BLOOD AMONG FUEL STATION EMPLOYEES AND ITS RELATIONSHIP TO IMPAIRED LIVER AND KIDNEY FUNCTIONS IN DAMASCUS; SYRIA: OCCUPATIONAL EXPOSURE TO LEAD Hassan Al-Mahbashi ${ }^{*}$ (D), Samira Asfoura ${ }^{2}$ (D), Saad Obri ${ }^{2}$ (D), Tareq Al-Maqtari ${ }^{3}$ (D), Abdulmalik Abudunia ${ }^{4}$ (D) \\ ${ }^{I}$ Department of Pharmacology and Toxicology Faculty of Pharmacy, Al-Kalamoon University, Syria. \\ ${ }^{2}$ Department of Biochemistry and Microbiology, Faculty of Pharmacy, Al-Kalamoon University, Syria. ${ }^{3}$ Department of Pharmacology, Faculty of Pharmacy, International University for science and Technology, Damascus, Syria. ${ }^{4}$ Department of Pharmacology, Faculty of Pharmacy, 21 Sep University of Medical and Applied Sciences, Yemen.
}

\section{ABSTRACT}

Objectives: Chronic exposure to lead is known to cause adverse health effects. Workers at fuel stations are exposed to high concentrations of lead during filling cars and through Car's emissions and being in contact with contaminated hands, food, water and clothing. This study was designed to find blood lead level and their adverse effects on kidney and liver function among fuel station workers.

Methods: Forty fuel station workers (exposed group) and thirty apparently healthy subjects (non-exposed group) in Damascus were randomly selected for the study. Blood lead levels were determined using Atomic absorption spectrometry after microwaveassisted acid digestion. Serum concentration of creatinine, uric acid and urea values were recorded to assess kidney function, whereas AST and ALT serum concentrations were used to evaluate liver function.

Results: The results showed a non-significant elevation of blood lead level in the exposed group (11.04 $\pm 10.36 \mu \mathrm{g} / \mathrm{dl}) \mathrm{compared}$ to the non- exposed group $(8.1 \pm 2.97 \mu \mathrm{g} / \mathrm{dl})$. Serum concentration of creatinine and uric acid were significantly elevated in the exposed group, but there was no change in AST and ALT serum levels.

Conclusion: It is concluded that blood lead levels of fuel station workers don't exceed the threshold that may cause kidney or liver dysfunctions.

Keywords: Lead hepatotoxicity, lead nephrotoxicity, occupational lead exposure.

Article Info: Received 5 March 2020; Revised 2 April; Accepted 4 May, Available online 15 May 2020

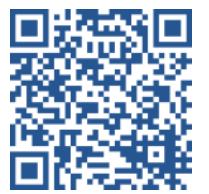

Cite this article-

Al-Mahbashi H, Asfoura S, Saad O, Al-Maqtari T, Abudunia A. Level of lead in the blood among fuel station employees and its relationship to impaired liver and kidney functions in damascus; Syria: occupational exposure to lead. Universal Journal of Pharmaceutical Research 2020; 5(2):10-15.

DOI: https://doi.org/10.22270/ujpr.v5i2.382

Address for Correspondence:

Prof. Hassan Al-Mahbashi, Department of Pharmacology and Toxicology Faculty of Pharmacy, Al-Kalamoon University, Syria, Tel: +963932648322, E-mail: hassanpharmad@gmail.com

\section{INTRODUCTION}

Heavy exposure to lead may cause serious adverse health issues especially among those who are exposed to it on a daily basis. Workers at fuel stations are heavily exposed to $\mathrm{lead}^{1}$, as gasoline contains an organic form of lead (tetraethyl lead) which is used as an antiknock agent ${ }^{2}$. Lead poisoning increase blood lead concentrations above the accepted concentrations of less than $10 \mu \mathrm{g} / \mathrm{dl}$ determined by the world health organization (WHO) ${ }^{3}$. Heavy exposure to lead has been associated with kidney and liver toxicity ${ }^{4,5}$. The kidney is often targeted by heavy metals due as it reabsorbs and concentrates divalent ions and metals during excretion. The severity of kidney impairment caused by lead depends on the type, dose, and duration of exposure $^{6}$. Acute lead exposure causes impairment of the proximal tubular architecture and induces histological changes such as eosinophilic intra-nuclear inclusions of lead-protein complexes in tubular cells and mitochondrial swelling. On the other hand, chronic exposure to lead may damage kidneys as manifested by increased urate secretion, vasoconstriction of renal blood vessels and consequent glomerulosclerosis, hypertension and interstitial fibrosis ${ }^{7,8}$. Lead exposure may also causes liver toxicity associated with changes in liver structure ${ }^{9,10}$. Lead in the body is metabolized inside the liver via glutathione conjugation. Thus, lead and its metabolite are concentrated in the liver ${ }^{11,12,13}$ leading to depletion of glutathione and increased oxidative stress, which aggravates liver 
impairment ${ }^{14,15,16,17}$. To the best of the authors' knowledge, no past studies have evaluated the blood lead level, and its correlation with liver and kidney function among fuel station workers as a result of their workplace in the city of Damascus (Syria). So this study was aimed at determining blood lead level and its correlation with kidney and liver dysfunctions among fuel station workers in Damascus.

\section{SUBJECTS AND METHODS}

A Comparative cross-sectional analysis was carried out on seventy subjects aged 19-61 years old in Damascus city during the period March-April 2019. A total of 40 human volunteers, who work in fuel stations in Damascus (Exposed group) were selected for the study. Another group of 30 healthy subjects whose work does not involve lead or gasoline exposure were utilized as the control group (non-exposed group). Exclusion criteria included subjects with hepatitis $\mathrm{B}$ or $\mathrm{C}$, cirrhosis, diabetes mellitus and malignancy. The volunteers participating in this study after filling consent form. All participants were given clear explanation regarding the methodology of the research. The present study was approved by the Institutional Ethical Committee, Faculty of Pharmacy (AlKalamoon University). A questionnaire for all volunteers was filled including the subject's personal and clinical information such as age, gender, occupation, no. of years working in a fuel station and daily hours spent on duty.

Samples collection and preparation

Blood sample of $5 \mathrm{ml}$ was taken from each volunteer through venipuncture, and the sample was divided into two halves: one to assess kidney function (creatinine, uric acid and urea), liver function (AST and ALT) and the other half to a tube containing EDTA to determine lead levels.

\section{Measuring lead levels of blood}

Lead level in blood was determined by atomic absorption spectrometry (AAS) (ZEE nit 700P, Germany). Blood samples were digested by the microwave-induced acid digestion method using the method of Kazi et al., and Yahaya et al., ${ }^{18,19}$. Three milliliters of freshly prepared mixture of concentrated nitric acid and hydrogen peroxide $(2: 1 \mathrm{~V} / \mathrm{V})$ were added to $0.5 \mathrm{ml}$ of whole blood sample. After $10 \mathrm{~min}$, the mixture was heated in a microwave oven (Berghof 'speed wave ${ }^{\circledR}$ four' microwave) with a high heating power $(800 \mathrm{~W})$ for 3 minutes. Then, the digestion flasks were left to cool. The resulting solutions were evaporated to semi-dried mass to get rid of excess acid, and then diluted by adding $0.1 \mathrm{M}$ nitric acid. A blank extraction (with no sample) solution was also prepared. Quantification of lead levels was then performed using an atomic absorption spectrophotometer.

\section{Biochemical assays}

Serum levels of AST, ALT, creatinine, uric acid and urea were determined using a spectrophotometer (Photometer 5010, Germany) and a commercially available kit according to the manufacturer's instructions (Eltech Group,). Hematocrit and hemoglobin were determined by an automated complete blood count (CBC) analyzer (Nihon Kohden, Japan).

\section{Data Analysis}

Statistical Package for Social Sciences (SPSS) version 23 was used to analyze the data. Numbers and percentages were used to describe demographic characters (Qualitative data). The normal distribution of data was tested using Kolmogorov-Smirnov test. Quantitative data were described as means \pm standard deviation (SD) or medians (range), depending on normality of data. Independent sample $t$-test and ANOVA were used to assess normally distributed data while Mann Whitney test and Kruskal Wallis Test were used for non-normally distributed data. A $p$ value of $\leq$ 0.05 was considered statistically significant.

Table 1: Demographic characteristics of study subjects.

\begin{tabular}{|c|c|c|c|c|}
\hline \multirow[t]{2}{*}{ Variables } & \multicolumn{2}{|c|}{ Exposed } & \multicolumn{2}{|c|}{ Non-exposed } \\
\hline & $\mathbf{N}$ & $\%$ & $\mathbf{N}$ & $\%$ \\
\hline \multicolumn{5}{|l|}{ Gender } \\
\hline Male & 40 & 100 & 30 & 100 \\
\hline Female & 0 & 0 & 0 & 0 \\
\hline Total & 40 & 100 & 30 & 100 \\
\hline \multicolumn{5}{|l|}{ Age } \\
\hline $19-45$ & 24 & 60 & 29 & 96.7 \\
\hline $46-60$ & 11 & 27.5 & 0 & 0 \\
\hline$>61$ & 5 & 12.5 & 1 & 3.3 \\
\hline Total & 40 & 100 & 30 & 100 \\
\hline \multicolumn{5}{|l|}{ Occupation } \\
\hline Fuel station & 40 & 100 & 0 & 0 \\
\hline Total & 40 & 100 & 0 & 0 \\
\hline \multicolumn{5}{|l|}{$\begin{array}{l}\text { Cigarette } \\
\text { smoking }\end{array}$} \\
\hline Yes & 27 & 67.5 & 16 & 53.3 \\
\hline No & 13 & 32.5 & 14 & 46.7 \\
\hline Total & 40 & 100 & 30 & 100 \\
\hline \multicolumn{5}{|c|}{$\begin{array}{l}\text { Years spent in } \\
\text { job }\end{array}$} \\
\hline$<1$ year & 6 & 15 & 0 & 0 \\
\hline $1-10$ years & 20 & 50 & 0 & 0 \\
\hline $11-20$ years & 4 & 10 & 0 & 0 \\
\hline $21-30$ years & 6 & 15 & 0 & 0 \\
\hline > 30 years & 4 & 10 & 0 & 0 \\
\hline Total & 40 & 100 & 0 & 0 \\
\hline \multicolumn{5}{|c|}{$\begin{array}{l}\text { Hours spent on } \\
\text { duty }\end{array}$} \\
\hline $1-3 \mathrm{hr}$ & 5 & 12.5 & 0 & 0 \\
\hline $4-6 \mathrm{hr}$ & 19 & 47.5 & 0 & 0 \\
\hline $7-10 \mathrm{hr}$ & 9 & 22.5 & 0 & 0 \\
\hline$>10 \mathrm{hr}$ & 7 & 17.5 & 0 & 0 \\
\hline Total & 40 & 100 & 0 & 0 \\
\hline
\end{tabular}

\section{RESULTS}

Table 1 showed the demographic characteristics of the exposed and non-exposed groups. All subjects in this study were male and ranged between 19 to 61 years old. In the exposed group, $60 \%$ were between 19-45 years old, $27.5 \%$ were $46-60$, and $12.5 \%$ were over 61 years old. $67 \%$ of the exposed group was smokers, while the proportion of smokers in the non-exposed group was $53.3 \%$. As for the period spent by workers in the service, it was found that $50 \%$ of them worked in gas stations for a period of 1-10 years. Regarding the daily working hours spent by workers, it was found 
that $47.5 \%$ worked for 4-6 hours. The findings show that there was no significant differences in $\mathrm{Hb}, \mathrm{HCT} \%$ and BMI between the exposed group and the nonexposed group (Table 2). When comparing blood lead levels in the exposed and control group Table 3, the median lead level for workers was $8.50 \mu \mathrm{g} / \mathrm{dl}$, and ranged between $5.40-66.50 \mu \mathrm{g} / \mathrm{dl}$, with mean \pm SD equal to $11.04 \pm 10.36 \mu \mathrm{g} / \mathrm{dl}$ compared with lower values for the non-exposed group $(8.15,3.10-15.80,8.1 \pm 2.97$ $\mu \mathrm{g} / \mathrm{dl})$, however, the difference was not significant $(P=0.29)$.

Table 2: Comparison of haematological parameters and BMI in the exposed and non-exposed groups.

\begin{tabular}{ccccc}
\hline Variables & $\begin{array}{c}\text { Non-Exposed } \\
(\mathbf{n = 3 0})\end{array}$ & $\begin{array}{c}\text { Exposed } \\
(\mathbf{n = 4 0})\end{array}$ & $\begin{array}{c}\mathbf{t} \\
\text { value }\end{array}$ & $\begin{array}{c}\boldsymbol{P} \\
\text { value }\end{array}$ \\
\hline HB & $14.79 \pm 1.06$ & $14.6 \pm 0.87$ & 0.809 & 0.421 \\
HCT\% & $46 \pm 3.3$ & $45.42 \pm 2.70$ & 0.800 & 0.426 \\
BMI & $25.2 \pm 4.75$ & $25.21 \pm 5.13$ & 0.062 & 0.950 \\
\hline \multicolumn{5}{c}{ Data are expressed as Means \pm Standard Deviations }
\end{tabular}

Table 3: Blood lead concentration $(\mu \mathrm{g} / \mathrm{dl})$ in the exposed and non-exposed groups.

\begin{tabular}{cccc}
\hline Variables & $\begin{array}{c}\text { Non- } \\
\text { Exposed(n=30) }\end{array}$ & $\begin{array}{c}\text { Exposed } \\
(\mathbf{n = 4 0})\end{array}$ & $\begin{array}{c}\boldsymbol{P} \\
\text { value }\end{array}$ \\
\hline $\mathrm{Lead}$ & $8.15(3.10-$ & $8.50(5.40-$ & 0.29 \\
$(\mu \mathrm{g} / \mathrm{dl})$ & $15.80)$ & $66.50)$ & \\
& $8.1 \pm 2.97$ & $11.04 \pm 10.36$ & \\
\hline
\end{tabular}

Data are expressed as median (range), mean \pm SD

As showed in Table 4, liver function determined by AST and ALT serum concentrations were normal in the exposed group compared to the non-exposed group $(P=0.83, \quad 0.75$ for AST and ALT respectively). However, the results revealed higher levels of serum creatinine and uric acid in the exposed group compared to the non-exposed group $(p<0.05)$.

Table 4: Comparison of AST, ALT, creatinine, uric acid and urea concentrations $(\mathrm{mg} / \mathrm{dl})$ in the exposed and non-exposed groups.

\begin{tabular}{|c|c|c|c|}
\hline $\begin{array}{l}\text { Variables } \\
(\mathrm{mg} / \mathrm{dl})\end{array}$ & $\begin{array}{c}\text { Non- } \\
\text { Exposed } \\
(\mathbf{n}=\mathbf{3 0})\end{array}$ & $\begin{array}{c}\text { Exposed } \\
(n=40)\end{array}$ & $\begin{array}{c}P \\
\text { value }\end{array}$ \\
\hline AST & $\begin{array}{c}19.4 \\
(6.7-40.5)\end{array}$ & $\begin{array}{c}25.1 \\
(6.7-56.2)\end{array}$ & 0.83 \\
\hline ALT & $\begin{array}{c}18.55 \\
(6.1-65.2)\end{array}$ & $\begin{array}{c}25.7 \\
(5.4-79.16)\end{array}$ & 0.75 \\
\hline Creatinine & $\begin{array}{c}0.65 \\
(0.51-1.02)\end{array}$ & $\begin{array}{c}0.94 \\
(0.8-1.16)^{*}\end{array}$ & 0.000 \\
\hline Uric acid & $\begin{array}{c}5.5 \\
(3.5-8.1)\end{array}$ & $\begin{array}{c}6.67 \\
(3.9-9.75)^{*}\end{array}$ & 0.000 \\
\hline Urea & $\begin{array}{c}25.6 \\
(18-42)\end{array}$ & $\begin{array}{c}27.05 \\
(16-51)\end{array}$ & 0.054 \\
\hline
\end{tabular}

Mann-Whitney Test was performed on the exposed group to assess effect of smoking on blood lead concentration. The results showed no significant difference $(P=0.42)$ between blood lead concentrations in the smoker compared to the non-smoker subjects (Table 5). Pearson's correlation coefficient was used to assess the impact of age, years and hours spent in job on blood lead concentration of exposed groups. As shown in Table 6, the analysis revealed a significant (moderate) positive correlation between blood lead concentration and age $(\mathrm{r}=0.312, P=0.05)$, and a significant positive moderate correlation between blood lead concentration and hours spent on job $(r=0.483$, $P=0.002$ )

Table 5: Blood lead level in smokers and nonsmokers of the exposed group.

\begin{tabular}{cccc}
\hline & Smoker & $\begin{array}{c}\text { Non- } \\
\text { smoker }\end{array}$ & $\begin{array}{c}\boldsymbol{P} \\
\text { value }\end{array}$ \\
\hline $\mathrm{Pb}(\mu \mathrm{g} / \mathrm{dl})$ & 8.6 & 8.4 & 0.42 \\
& $(5.4-26.4)$ & $(6.1-66.5)$ & \\
\hline \multicolumn{4}{c}{ Data are expressed as median (range) }
\end{tabular}

Table 7 show blood lead level, serum concentration of AST and ALT according to age, years and daily hours spent on job. The data reveal that lead concentration in blood was higher in subjects aged over 61 year but this elevation was not significant compared to other age intervals.

Table 6: Pearson's correlation coefficients (r) between $\mathrm{Pb}$ blood level and age, Years spent on job, hours spent on job in the exposed group.

\begin{tabular}{lcc}
\hline Variables & $\mathbf{r}$ & $\boldsymbol{P}$ value \\
\hline Age & 0.312 & $0.05^{*}$ \\
Years spent on job & 0.271 & 0.9 \\
Daily hours spent on job & 0.483 & $0.002^{* *}$ \\
$=$ \\
$\begin{array}{l}\text { Correlation is significant at the } 0.05 \text { level, }{ }^{* *}=\text { Correlation is } \\
\text { significant at the } 0.01 \text { level }\end{array}$
\end{tabular}

The blood lead concentration also increased with the increase of years and hours of works spent in fuel stations, but this elevation was not statistically significant. In addition, working years and hours on duty did not significantly affect serum lead levels. Regarding kidney function, no significant differences in creatinine, uric acid or urea levels were observed in the different age groups nor in the groups with different working years and working hours (Table 8).

\section{DISCUSSION}

Leaded gasoline has been identified as a significant predictor for increased blood lead levels in fuel station workers. No previous studies have been determined blood lead concentrations of fuel station workers in Syria and their toxicity on kidney and liver. Unexpectedly, the data obtained in this study showed that the mean blood lead concentration of fuel station workers was not significantly different from the nonexposed group. The mean lead level in the exposed group was $11.04 \mu \mathrm{g} / \mathrm{dl}$ (the highest concentration found was $66.50 \mu \mathrm{g} / \mathrm{dl}$ and the lowest was $8.10 \mu \mathrm{g} / \mathrm{dl})$. This is in agreement with a previous investigation that took place in Gaza Strip ${ }^{20}$, and found that $11.4 \mu \mathrm{g} / \mathrm{dl}$ was the mean blood lead concentration in fuel station personnel. However, other studies performed in other countries have reported higher blood level concentrations. The means were $45.43 \mu \mathrm{g} / \mathrm{dl}$ in Abuja, Nigeria $^{21}, 15.11 \mu \mathrm{g} / \mathrm{dl}$ in Nnewi, Nigeria ${ }^{22}, 14.1 \mu \mathrm{g} / \mathrm{dl}$ in Basrah, Iraq ${ }^{23}, 33.6 \mu \mathrm{g} / \mathrm{dl}$ in Khartoum, Sudan ${ }^{24}$ and $30.05 \mu \mathrm{g} / \mathrm{dl}$ in $\operatorname{Iran}^{25}$. On the other hand, there are other studies that reported lead concentrations that are lowers 
than found in the present work. For instance, the mean lead concentration was reported $3.5 \mu \mathrm{g} / \mathrm{dl}$ in Denmark $^{26}, 8.6 \mu \mathrm{g} / \mathrm{dl}$ in Ghana ${ }^{27}$, and $5.6 \mu \mathrm{g} / \mathrm{dl}$ in Greece $^{28}$. Low blood lead level in these three countries may be due to implementing effective contamination prevention and intervention programs regarding lead chronic intoxication as well as to the presence of effective surveillance of the health status of all fuel station workers. According to the WHO, the acceptable blood concentration of lead in adults should not exceed $10 \mu \mathrm{g} / \mathrm{dl}^{3}$. Based on these criteria, $77.5 \%$ of the fuel station workers had acceptable blood lead levels (see Table 9), and $22.5 \%$ had higher than acceptable level.

Table 7: Blood concentration of lead, serum concentration of AST and ALT in the exposed group according to age working years and working hours.

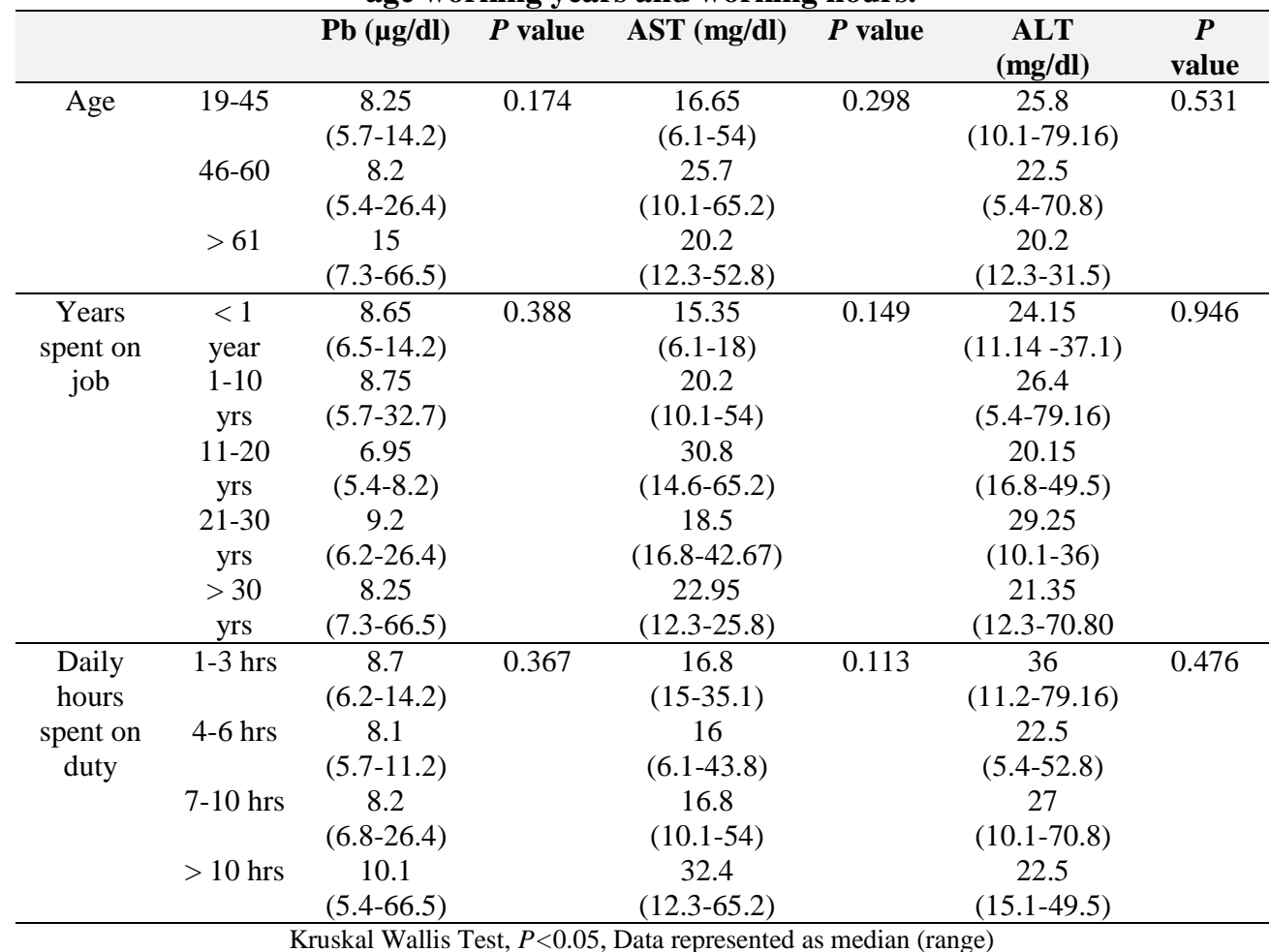

Table 8: serum concentration of creatinine, uric acid and urea in the exposed group according to age working years and working hours.

\begin{tabular}{|c|c|c|c|c|c|c|c|}
\hline & & $\begin{array}{c}\text { Creatinine } \\
(\mathrm{mg} / \mathrm{dl})\end{array}$ & $P$ value & $\begin{array}{c}\text { Uric acid } \\
\text { (mg/dl) }\end{array}$ & $P$ value & $\begin{array}{c}\text { Urea } \\
\text { (mg/dl) }\end{array}$ & $P$ value \\
\hline \multirow[t]{3}{*}{ Age } & $19-45$ & $\begin{array}{c}0.94 \\
(0.8-.16)\end{array}$ & 0.95 & $6.77 \pm 1.07$ & 0.071 & $28.6 \pm 8.38$ & 0.186 \\
\hline & $46-60$ & $\begin{array}{c}1.015 \\
(0.87-1.09)\end{array}$ & & $6.50 \pm 1.13$ & & $27.64 \pm 5.07$ & \\
\hline & $>61$ & $\begin{array}{c}0.94 \\
(0.87-1.09) \\
\end{array}$ & & $7.91 \pm 1.24$ & & $34.9 \pm 7.11$ & \\
\hline \multirow{7}{*}{$\begin{array}{c}\text { Years } \\
\text { spent on } \\
\text { job }\end{array}$} & $<1$ year & $\begin{array}{c}0.94 \\
(0.87-1.09)\end{array}$ & 0.377 & $6.70 \pm 0.60$ & 0.188 & $27.35 \pm 4.49$ & 0.39 \\
\hline & $1-10 \mathrm{yrs}$ & $\begin{array}{c}1.01 \\
(0.80-1.16)\end{array}$ & & $6.92 \pm 1.33$ & & $27.65 \pm 8.64$ & \\
\hline & $\begin{array}{c}11-20 \\
\text { yrs }\end{array}$ & $\begin{array}{c}0.94 \\
(0.87-1.02)\end{array}$ & & $5.81 \pm 0.45$ & & $29.22 \pm 8.18$ & \\
\hline & $21-30$ & 0.94 & & $6.75 \pm 1.26$ & & $31.75 \pm 6.59$ & \\
\hline & yrs & $(0.87-1.02)$ & & & & & \\
\hline & $>30$ & 0.97 & & $7.81 \pm 0.24$ & & $35.1 \pm 5.41$ & \\
\hline & yrs & $(0.94-1.09)$ & & & & & \\
\hline \multirow{4}{*}{$\begin{array}{l}\text { Daily } \\
\text { hours } \\
\text { spent on } \\
\text { job }\end{array}$} & $1-3 \mathrm{hrs}$ & $\begin{array}{c}1.01 \\
(0.87-1.02)\end{array}$ & 0.649 & $7.69 \pm 0.93$ & 0.248 & $29.62 \pm 8.24$ & 0.996 \\
\hline & 4-6 hrs & $\begin{array}{c}0.94 \\
(0.8-1.16)\end{array}$ & & $6.68 \pm 0.94$ & & $29.17 \pm 8.29$ & \\
\hline & $7-10 \mathrm{hrs}$ & $\begin{array}{c}0.94 \\
(0.87-1.09)\end{array}$ & & $6.5 \pm 1.10$ & & $29.2 \pm 4.97$ & \\
\hline & $>10 \mathrm{hrs}$ & $\begin{array}{c}1.01 \\
(0.94-1.09)\end{array}$ & & $7.11 \pm 1.71$ & & $28.54 \pm 9.67$ & \\
\hline
\end{tabular}

Kruskal Wallis Test, $P<0.05$, Data represented as median (range), ANOVA test, $P<0.05$, Data represented as mean \pm SD 
Table 9: Numbers and \% of subjects in the exposed groups whose blood lead concentration were $<$ or $\geq 10 \mu \mathrm{g} / \mathrm{l}$.

\begin{tabular}{cccccc}
\hline & Number & $\%$ & $\begin{array}{c}\text { Pb }(\boldsymbol{\mu g} / \mathbf{d l}) \\
\text { Mean }\end{array}$ & $\begin{array}{c}\text { Pb }(\boldsymbol{\mu g} / \mathbf{d l}) \\
\text { Median }(\text { range })\end{array}$ & $\begin{array}{c}\boldsymbol{P} \text { - } \\
\text { value }\end{array}$ \\
\hline$<10 \mu \mathrm{g} / \mathrm{l}$ & 31 & 77.5 & 7.79 & $7.9(5.4-9.9)$ & $6 \times 10^{-6}$ \\
$\geq 10 \mu \mathrm{g} / 1$ & 9 & 22.5 & 22.24 & $14.2(10.1-66.5) *$ & \\
\hline \multicolumn{5}{l}{ Data are expressed as median (range), ${ }^{*} P$-value is significant at the level of $<0.05}$.
\end{tabular}

The data also show considerable variance in blood lead levels among fuel station workers which may be ascribed to variance in years and daily hours spent on duty. Table 10 indicates an in increase in blood lead level in those with longer years and hours spent working. The data showed a significant positive correlation between blood lead level and hours spent on job ( $\mathrm{r}=0.483, P=0.002)$ (Table 6). In accordance with current findings, Nurjazuli et al. ${ }^{29}$ have demonstrated in 2003 that time spent at work is a significant predictor of blood lead levels, and Stoleski et al. ${ }^{30}$ revealed a direct correlation between blood lead concentration and work duration and occupational lead exposure.

Table 10: Blood lead level according to years daily hours spent in work in the exposed group.

\begin{tabular}{ccc}
\hline & & Pb $\boldsymbol{\mu g} / \mathbf{l}$ (mean) \\
\hline Duration & $<1$ year & 8.9 \\
(years) & $1-10 \mathrm{yrs}$ & 9.83 \\
& $11-20 \mathrm{yrs}$ & 6.87 \\
& $21-30 \mathrm{yrs}$ & 12.3 \\
& $>30 \mathrm{yrs}$ & 22.57 \\
\hline Time (hrs) & $1-3 \mathrm{hrs}$ & 9.04 \\
& $4-6 \mathrm{hrs}$ & 8.05 \\
& $7-10 \mathrm{hrs}$ & 11.46 \\
& $>10 \mathrm{hrs}$ & 20.04 \\
\hline
\end{tabular}

Occupational lead exposure could impair kidney functions on the long run ${ }^{31}$. The data obtained in this work reveal a significant elevation in plasma concentrations of creatinine and uric acid in the exposed group, but their serum concentration was still within the physiological norms. In accordance, a previous work concluded that lead-exposed workers with low blood lead level of less than $7 \mu \mathrm{g} / \mathrm{dl}$ did not suffer from lead-related kidney dysfunction ${ }^{32}$. Also, there was no change in serum creatinine and uric acid in subjects with high blood lead levels of $36 \mu \mathrm{g} / \mathrm{dl}$. The renal dysfunction seems to develop only when blood lead levels exceeds a threshold of $60 \mu \mathrm{g} / \mathrm{dl}^{8}$. The liver function of the exposed group was assessed using serum AST and ALT activities. The results did not show a significant difference in serum concentration of serum AST and ALT between the exposed group and non-exposed group. In the same manner, Allouche and his colleagues ${ }^{33}$ reported no disturbance in biochemical liver parameters in people with extensive previous exposure to lead. Another study on two occupationally lead-exposed groups with moderately elevated blood lead levels, showed a non-significant differences in AST and ALT levels compared to the non-exposed group $^{34}$, and that only those with exceedingly high lead levels had hepatic dysfunction ${ }^{35}$. Therefore, the normal serum concentration of AST and ALT of the exposed group in this investigation may be because blood lead level is still below the threshold that causes liver dysfunction.

\section{CONCLUSION}

The present study confirms that fuel station workers in Damascus city (Syria) had a mean blood lead level that is not statistically different from the rest of the society. The normality of blood lead level may be due to the short time fuel station workers spent in the working place. In addition, these workers did not suffer from work-related liver impairment, but they suffer from a significant elevation in serum concentration of creatinine and uric acid, but their serum concentration were still within the physiological norms, possibly due to the blood lead level being below the threshold value that causes renal/hepatic disturbance. The findings support the notion that policies controlling lead exposure in the working place dictates the health outcomes in lead-exposed personnel.

\section{AUTHOR'S CONTRIBUTION}

HA, SA designed the study and assisted in the interpretation of data. SO, HA assisted with practical work. HA wrote the manuscript, statistics and give the final approval of version to be published. TA and AA assisted in interpretation and language revision. All authors read and approved the final manuscript.

\section{ACKNOWLEDGEMENTS}

The authors are thankful for all members of pharmacology and toxicology lab. (Al-Kalamoon University) for their assistance.

\section{CONFLICT OF INTERESTS}

No conflict of interest associated with this work

\section{REFERENCES}

1. Orisakwe OE. Environmental pollution and blood lead levels in Nigeria: who is unexposed? Int $\mathrm{J}$ Occup Environ Health 2009; 15(3):315-317. https://doi.org/10.1179/oeh.2009.15.3.315

2. Kovarik W. Ethyl-leaded gasoline: how a classic occupational disease became an international public health disaster. Int J Occup Environ Health. 2005; 11(4):384-397. https://doi.org/10.1179/oeh.2005.11.4.384

3. Joint W, Organization WH. Health risks of heavy metals from long-range transboundary air pollution. Copenhagen: WHO Regional office for Europe 2007.

4. Adeniyi T, Ajayi G, Sado M, et al. Vitamin C and garlic (Allium sativum) ameliorate nephrotoxicity and biochemical alterations induced in lead-exposed rats. J Med Med Sci 2012; 3:273-280

5. Bartimaeus E, Jacobs M. The effect of exposure to petroleum products on some renal function parameters of motor mechanics in Port Harcourt Metropolis of Nigeria. Global J Pure App Sci 2003; 9(1):59-64. https://doi.org/10.4314/gjpas.v9i1.15980

6. Lentini P, Zanoli L, Granata A, et al. Kidney and heavy metals-The role of environmental exposure. Molecular Med Rep 2017; 15(5):3413-3419. 
https://doi.org/10.3892/mmr.2017.6389

7. Patrick L. Lead toxicity, a review of the literature. Part I: Exposure, evaluation, and treatment. Alt Med Rev 2006; 11(1).

8. Loghman-Adham M. Renal effects of environmental and occupational lead exposure. Environ Health Perspect 1997; 105(9):928-939. https://doi.org/10.1289/ehp.97105928

9. Piasek M, Kostial K, Bunarević A. The effect of lead exposure on pathohistological changes in the liver and kidney in relation to age in rats. Arhiv Za Higijenu Rada I Toksikologiju 1989; 40(1):15-21.

10. Jarrar B. Histological, histochemical and ultrastructural alterations induced by lead in the kidney and liver of male Wistar albino rats. Ph. D. Thesis, University of Khartoum 1999. https://doi.org/10.5144/0256-4947.2003.10

11. U.S. E. Air Quality Criteria for Lead. Environmental Criteria and Assessment Office. 1986; 1: NC. EPA-6001860083/60028aF

12. Abadin H, Ashizawa A, Llados F, et al. Toxicological profile for lead. 2007.

13. Yagminas A, Franklin C, Villeneuve D, et al. Subchronic oral toxicity of triethyl lead in the male weanling rat. Clinical, biochemical, hematological, and histopathological effects. Toxicol Sci 1990; 15(3):580-596. https://doi.org/10.1093/toxsci/15.3.580

14. Skerfving S. Biological monitoring of exposure to inorganic lead. Biological monitoring of toxic metals: Springer 1988:169-197.

15. Flora S, Kumar D, Sachan S, et al. Combined exposure to lead and ethanol on tissue concentration of essential metals and some biochemical indices in rat. Biol Trace Element Res 1991; 28(2):157-164. https://doi.org/10.1007/BF02863081

16. Shinozuka H, Ohmura T, Katyal SL, et al. Possible roles of nonparenchymal cells in hepatocyte proliferation induced by lead nitrate and by tumor necrosis factor $\alpha$. Hepatology. 1996; 23(6):1572-1577. https://doi.org/10.1002/hep.510230638

17. Taib N, Jarrar B, Mubarak M. Ultrastructural alterations in hepatic tissues of white rats (Rattus norvegicus) induced by lead experimental toxicity. Saudi J Biol Sci 2004; 11(1):1120.

18. Kazi TG, Afridi HI, Jamali MK, et al. Evaluation of zinc status in whole blood and scalp hair of female cancer patients. Clinica Chimica Acta 2007; 379(1-2):66-70. https://doi.org/10.1016/j.cca.2006.12.009

19. Yahaya M, Shehu A, Dabai F. Efficiency of extraction of trace metals from blood samples using wet digestion and microwave digestion techniques. J App Sci Env Manag 2013; 17(3):365-369. https://doi.org/10.4314/jasem.v17i3.4

20. Yassin MM, Lubbad AMM. Blood lead level in relation to awareness and self reported symptoms among gasoline station workers in the Gaza strip. J Medicine 2013; 14:2.

21. Alli LA. Blood level of cadmium and lead in occupationally exposed persons in Gwagwalada, Abuja, Nigeria. Interdisc Toxicol 2015; 8(3):146-150. https://doi.org/10.1515/intox-2015-0022

22. Ibeh N, Aneke J, Okocha C, et al. The influence of occupational lead exposure on haematological indices among petrol station attendants and automobile mechanics in Nnewi, South-East Nigeria. J Environ Occup Sci 2016; 5(1):1. https://doi.org/10.5455/jeos.20160320022500

23. Al-Rudainy LA. Blood lead level among fuel station workers. Oman Medical J 2010; 25(3):208. https://doi.org/10.5001/omj.2010.58

24. Tayrab E, Abdelrahman N, Tirba AK. Blood lead level among fuel station workers at Khartoum city. American J Res Comm 2014; 2(6):74-82.

25. Bahrami A, Mahjoub $H$, Asari M. A study of the relationship between ambient lead and blood bead among gasoline-station workers 2002.

26. Nielsen J, Grandjean P, Jørgensen P. Blood lead concentration in the Danish population after introduction of lead-free gasoline. Ugeskrift for laeger 1998; 160(33):47684771.

27. Ankrah N, Kamiya Y, Appiah-Opong R, et al. Lead levels and related biochemical findings occurring in Ghanaian subjects occupationally exposed to lead. East African Med J 1996; 73(6):375-379.

28. Kapaki EN, Varelas PN, Syrigou AI, et al. Blood lead levels of traffic-and gasoline-exposed professionals in the city of Athens. Archives Env Health: An Int J 1998; 53(4):287291.https://doi.org/10.1080/00039899809605710

29. Sirivarasi J, Kaorjaren S, Wananukul W, Srisomerg P. Nonoccupational determinants of cadmium and lead in blood and urine among a general population in Thailand. Southeast Asian J Trop Med Public Health 2002; 33:180-7.

30. Stoleski S, Karadžinska-Bislimovska J, Stikova E, et al. Adverse effects in workers exposed to inorganic lead. Arhiv Higijenu Rada Toksikologiju 2008; 59(1):19-29. https://doi.org/10.2478/10004-1254-59-2008-1866

31. Landrigaim PJ, Goyer RA, Clarkson TW, et al. The workrelatedness of renal disease. Archives of Environmental Health: An Int J 1984; 39(3):225-230. https://doi.org/10.1080/00039896.1984.9939529

32. Omae K, Sakurai H, Higashi T, et al. No adverse effects of lead on renal function in lead-exposed workers. Indust Health $1990 ; 28(2): 77-83$ https://doi.org/10.2486/indhealth.28.77

33. Allouche L, Hamadouche M, Touabti A, et al. Effect of long-term exposure to low or moderate lead concentrations on growth, lipid profile and liver function in albino rats. Adv Biol Res 2011; 5(6):339-347.

34. Can S, Bağci C, Ozaslan $\mathrm{M}$, et al. Occupational lead exposure effect on liver functions and biochemical parameters. Acta Physiologica Hungarica 2008; 95(4):395403. https://doi.org/10.1556/APhysiol.95.2008.4.6

35. Mazumdar I, Goswami K. Chronic exposure to lead: a cause of oxidative stress and altered liver function in plastic industry workers in Kolkata, India. Indian J Clin Biochem 2014; 29(1):89-92. https://doi.org/10.1007/s12291-013-0337-9 